УДК 340.12

https://doi.org/10.33989/2075-1443.2020.43.212696

orcid.org/ 0000-0002-0606-0544

\title{
Ірина Матвієнко
}

МАТВІСНКО Ірина Серхї̈вна - кандидат філософських наук, дочент кафедри філософії Національного університету біоресурсів $i$ природокористування України (м. Київ). Сфера наукових інтересів методологія наукового дослідження, логіка, теорія аргументаиії.

\section{ТЕОРІЯ АРГУМЕНТАЦІЇ: ФОРМАЛЬНА CONTRA НЕФОРМАЛЬНА ЛОГІКА}

У статті представлено дослідження теорії аргументаиіі через дві бінарні позиції, а саме формальну та неформальну логіку. Формальний підхід до теорії аргументації дає чітку структуру, формальні умови та систему аргументачіï, але як показує життєва практика для того, щоб переконати не достатньо мати істинні судження та формулювати правильні умовиводи відповідно до основних законів логіки. Для переконливості в своій аргументації слід використовувати і неформальні методи, адже комунікаиія між людьми носить відносний, не сталий характер.

Теорію аргументаиії на сьогодні досліджують в різних сфера життедіяльності людини, i хоча ї̈ витоки сягають часів Аристотеля, на сьогодні иим питанням крім філософії та логіки займаються, ще й такі дисиипліни як психологія, юриспруденція, політологія, філологія та багато інших. Саме ие визначає той факт, щяо до теорії аргументації вибудовуються все нові i нові підходи ї̈ дослідження та вивчення. Традичійна теорія аргументації є формальною, $і$ вона принщипово відрізняється від сучасної, для якої теоретичних відповідей вже недостатньо, а потрібні чіткі практичні настанови. Цей розрив між теорією та практикою в науиі XIX-XX століття дав можливість сформулювати неформальний підхід до теорії аргументації.

Ключові слова: мислення, аргументація, формальна логіка, неформальна логіка, реальна аргументація.

(C) I. С. Матвієнко, 2020 
Постановка проблеми. Виклики XXI століття визначають для нас нові завдання, для яких не достатнім є лише теоретичні відповіді на запитання, практика займає передове місце, саме тому до логіки як науки ставляться нові завдання перейти з теоретичної науки у практичну. Від логіки, яка займається мисленням людини, вимагається давати практичні відповіді на запитання. Саме тому, розгляд теорії аргументації $\epsilon$ цікавим, як з точки зору теоретичного, так і практичного iii застосування, що і пропонує нам формальна та неформальна логіка.

Аналіз дослідження і публікацій. Протягом всієї історії розвитку логічного знання теорія аргументації завжди мала своїх прихильників, починаючи від Аристотеля, Л. Вали, П. Абеляра, Г. Лейбниця, І. Канта, Л. Вітгенштейна, Г. Х. фон Врігта, Г. Фреге, Б. Расела, А. Тарського і інших, що сформували, так би мовити, формальний підхід до теорії аргументації. Неформальний підхід досліджувався наступними представниками С. Тулмін, Х. Перельман, Ф. ван Єємерен, Е. Блейр, Я. Хінтіка, Р. Джонсон, Дж. Фрідман, Д. Хічкок та інші. Українські дослідники, які займалися даним питанням представлені іменами А. Т. Ішмуратов, С. Б. Кримський, І. В. Хоменко, М. В. Попович, В. О. Бочаров, Ю. В. Івлєв, А. І. Уйомовта інші.

Метою нашого дослідження $є$ аналіз теорії аргументації крізь призму формальної та неформальної логіки.

Виклад основного матеріалу. Теорію аргументації на сьогодні досліджують в різних сфера життєдіяльності людини, і хоча її витоки сягають часів Аристотеля, на сьогодні цим питанням крім філософії та логіки займаються, ще й такі дисципліни як психологія, юриспруденція, політологія, філологія та багато інших. Саме це визначає той факт, що до теорії аргументації вибудовуються все нові і нові підходи іiї дослідження та вивчення. Традиційна теорія аргументації є формальною, і вона принципово відрізняється від сучасної, для якої теоретичних відповідей вже недостатньо, а потрібні чіткі практичні настанови. Цей розрив між теорією та практикою в науці XIX-XX століття дав можливість сформулювати неформальний підхід до теорії аргументації.

У витоків формування неформального підходу до аргументації стояли С. Тулмін та Х. Перельман, які вбачали в формальній логіці певні недоліки. С. Тулмін вважав, що судження, які використовуються в різних сферах мають залежати не від універсальних стандартів формулювання судження, а від конкретних ситуацій в яких вони застосовуються. X. Перельман, говорив про те, що в зв'язку з розвитком математики, логіка перейшла на рівень теоретичних математично доведених аргументів, але при цьому не звертала увагу на гуманітарні науки та можливості доказів для них. Адже, гуманітарна сфера має 
справу з цінностями, тому система аргументації, яка працює в точних науках для гуманітарних не є прийнятною. Ці дослідники вважали, що необхідно створити нову логіку, яка б була ближчою до епістемології і включала б в процес аргументації не ідеальні системи, як у формальній логіці, а конкретні ситуації, які пов'язані з життєдіяльністю людей. На сьогодні ці питання $є$ актуальними, адже теорія аргументації заполоняє все нові і нові сфери, і вони не можуть обмежуватися лише формально-логічним мисленням. Саме тому, починаючи з середини XX століття ця тема набуває все більшої популярності: проводяться конференції, семінари, випускаються журнали та монографії, які присвячені теорії аргументації, критичному мисленню, неформальній логіці, а також дотичними спеціальностям, таким як когнітивна психологія, риторика та іншим.

Ідея неформальної логіки, виникла через бажання як студентів, так і викладачів давати практично-конкретні відповіді на запитання, які б були близькими до практичного життя людей. 3 моменту свого виникнення неформальна логіка (informal logic) визначає себе як практична дисципліна, предметом іiї дослідження, на думку іiї засновників, $\epsilon$ висловлення в природній мові, при цьому використовуючи в природному дискурсі аргументацію, для якої є характерним багатозначність, невизначеність і неповнота ії складових. Але для практичних дій необхідно мати і теоретичну основу, що для неформальної логіки $€$ складним питанням, адже чіткої структури вона все ж таки не має, i навіть питання визначення, що ж таке неформальна логіка все ще відкрите для точного визначення.

Дослідження літератури дає можливість певним чином узагальнити питання визначення поняття «неформальна логіка». Досить часто в сучасній літературі, це поняття протиставляють формальній логіці, основою дослідження якої є поняття, судження та умовиводи в контексті кон'юнкції, диз'юнкції, імплікації, які ототожнюють з такими поняттями як «простір», «час» і іншими. 3 іншого боку, неформальна логіка визначається як вектор дослідження неформальних помилок та помилок в думках людей. Інший погляд на неформальну логіку - це розгляд іiі як формальної, але без формалізму. Уваги також заслуговує погляд на неформальну логіку як певний вид формальної але такої, яка пов'язана 3 процесом комунікації і роздумами людей,а також як певну методологію використання епістемологічних способів для оцінки аргументації. I найзагальніше розуміння неформальної логіки як нормативної науки, яка досліджує аргументацію та практику критичного мислення, саме ця сфера розробляє критерії, стандарти та процедури для оцінки, інтерпретації та побудови аргументації в мові (Хоменко, 2013, с. 89). 
Велика кількість визначень поняття «неформальна логіка» не дають нам узагальненого розуміння цього поняття. Аналіз та синтез різних точок зору не дають і єдино вірного терміну для даного напряму дослідження, деякі дослідники вважають, що поняття «неформальна логіка» повністю не визначає даний напрям. Саме тому, питання назви та визначення «неформальної логіки» потребує дослідження, адже питання практичної логіки, критичного мислення та міркувань в теорії аргументації є надзвичайно актуальним для сьогодення.

Формальний підхід до теорії аргументації дає чітку структуру, формальні умови та систему аргументації, так Аристотель у своїй роботі «Топіка» визначає поняття умовивід, як основу аргументації «це мова в якій якщо щось допускається, то через це припущення з необхідністю витікає дещо відмінне від даного. Докази є тоді, коли умовивід складається з істинних і перших [положень] або з таких, знання про які беруть свій початок від тих чи інших перших і істинних [положеннях]» (Хоменко, 1978, с. 349), але як показує життєва практика для того, щоб переконати не достатньо мати істинні судження та формулювати правильні умовиводи відповідно до основних законів логіки. Для переконливості в своїй аргументації слід використовувати і неформальні методи, адже комунікація між людьми носить відносний, не сталий характер.

3 моменту виникнення «неформальної логіки» (кін. 1970 р.) питання відношення до формальної логіки активно обговорюється та досліджується, і головним питанням є питання відношення даної дисципліни до формальної логіки взагалі. Так, наприклад, в роботі А. I. Уемова, читаємо: «будь яка логіка формальна; якщо вона претендує на те, щоб не бути формальною, то вона і не є логікою» (Уемов, 1997, с. 7), таку ж позицію в своїх роботах висуває і Я. Хінтікка. Інша точка зору, яка $є$ популярною в сучасній науковій літературі, і повністю протиставляється першій, вважається, що неформальна логіка тісто пов'язана $з$ логічним знанням. Так, Дж. Фріман, в своїй статті «Місце неформальної логіки в філософії» зазначає: «Що таке логіка? Класичною відповіддю на це питання $є$ те, що логіка вчить оцінювати міркування чи аргументації... В відповідності з цим визначенням не виникає сумніву, що неформальна логіка є логікою» (Freeman, 2000, pp. 117-128). Голандський вчений Ф. ван Еемерен зазначав, що неформальна логіка ближче до теорії та практики аргументації, ніж до формальної логіки. Е. Блейр і Р. Джонсон в своїй праці «Неформальна логіка: минуле та теперішнє» пишуть: «Неформальна логіка може бути розглянута як сфера теорії аргументації. Іншими словами, для будь якої теорії аргументації необхідним компонентом має стати теорія не- 
формальної логіки» (Johnson, \& Blair, 1994, p. 15). Д. Хічкок, вважає, що для теорії аргументації важливим є як неформальні, так і формальні логічні підходи, адже в різних ситуаціях потрібні різні підходи. Відмінність неформальної логіки складається з того, що в розгляді багатої кількості запитань, які не $є$ предметом обговорення чи дослідження важливі неформальні підходи до доведення, але з іншого боку, часто в дослідженнях найкращим аргументом є формально-логічні методи, які є визначальними в традиційній логіці.

Розглянемо формальний та неформальний підходи до теорії аргументації. В формальній логіці теорію аргументації та доведення вивчають 3 точки зору нормативної науки, тоді як в неформальному підході можливий як нормативний, так і дескриптивно-нормативний підходи. В побудові аргументації, коли ми говоримо про формальну логіку, то тут працюють виключно нормативні критерії, стандарти та процедури, що розглядають аргументацію, як вивідну структуру. Коли ж побудовою доведення займається неформальна логіка, то вона розробляє свої власні неформальні критерії, процедури та стандарти, вибудовуючи доведення розглядаючи його як певний вид діалогу, при цьому використовуючи природну мову, на противагу формальній логіці, де використовується виключно штучна мова логіки. В межах формальної логіки використовуються виключно формальні методи, аналізується тільки мікроструктура та форма аргументації, ії оцінка здійснюється, як правильна чи не правильна, де критерієм успіху є правильність побудови відповідно до формальних вимог та законів логіки. Тоді як у неформальній логіці аналізується макроструктура аргументації і методи побудови діаграм, оцінка ж доведення здійснюється, як хороша або погана, а успіх аргументації визначається через такі поняття, як релевантність, допустимість або достатність для переконання. Неформальний підхід базується на поєднанні теорії та практики, тоді як формальний підхід це виключно теоретичний підхід.

Неформальну логіку цікавить аналіз виключно «реальних» аргументів, які працюють, хоча сам термін «реальна аргументація» чітко не $є$ визначеним, хоча і займає домінантне місце в усій неформальній логіці. На сьогодні, цей термін досить часто вживається на позначення аргументації, яка використовується поза навчальною аудиторією, в диспутах, дискусіях, суперечці, це аргументація, яка використовується в коментарях до різних політичних та соціальних процесів, в соцмережах, інформаційному просторі та засобах масової інформації тай в повсякденному житті людей. Але все ж чи вичерпали ми цим переліком все значення «реальної аргументації», і чи має вона відношення до формальної? В сучасній літературі, в більшій своїй частині, в ан- 
гломовній, розглядають аргументацію через два поняття «вид діалогу» та «вид висновку». «Вид діалогу» вимагає від аргументації, на думку Д. Хічкока, мінімум двох співрозмовників, де кожен висловлює свою думку і деякі запитання, де завдання кожного члена діалогу переконати в своїй точці зору, використовуючи для цього і емоційні аргументи також. (Hitchcock, 2007, p. 102). Коли ж ми говоримо про «вид висновку», то тут Д. Хічкок, вже зазначає, що ми маємо лише доповідача, тобто того, хто висуває тезу та використовуючи один або більше аргументів намагається донести свою позицію до слухача або читача, зазвичай аргументи, які використовуються не носять емоційного забарвлення. Коли ми вживаємо поняття аргументація, то розуміємо, що це має бути чітко структурований текст чи доповідь, яка підкріплена одним або більше аргументами і має певний висновок, правила за якими вибудовується аргументація і критерії якості такої аргументації, і $€$ предметом дослідження логіки. Але все ж єдиновірного визначення, що таке «реальна аргументація» не має, ми можемо знайти безліч визначень, кожне з яких буде розкривати нові грані цього поняття.

Достатньо дискусійним є питання про склад аргументації, якщо ми говоримо про формальну аргументацію, то тут все чітко є теза, аргументи і демонстрація, коли ж ми говоримо про неформальну аргументацію, то тут теж постають питання з приводу її структури. Досить часто виділяють дві складові це теза або інколи визначають, як точка зору і аргументи, інколи структуру аргументації інтерпретують, як модель, яку вводить в загальний вжиток С. Тулмін, і тут дослідник визначає шість компонентів, а саме: ствердження (claim), данні (data, later grounds), основи (warrant), підтримки (backing), кваліфікатор (modal qualifier), спростування (rebuttal) (Хоменко, 2013, с. 96). Ще один підхід, який $є$ достатньо популярним в наукових колах, визначає склад аргументації, як засновки, висновок і діалектична складова, його підтримують такі логіки, як Р. Джонсон, Л. Грорке і інші.

Отже, підводячи підсумки, ми маємо визнати наступне, що якщо ми говоримо про неформальну аргументацію (реальну аргументацію), то до цієї теми в сучасній літературі більше запитань ніж відповідей, 3 приводу ж формальної аргументації, то тут все чітко і структуровано відповідно до логічних критеріїв формальної логіки, але що ж робити 3 тими суб єктивними питаннями, які вона не враховує, хоча вони в аргументації мають важливе значення. I хоч з кінця 1970-х pp. і по даний час неформальна логіка позиціонує себе як наукова область знань, але в ії межах, більше запитань ніж відповідей до важливих, ми б сказали основопокладаючих понять, на які нема істинно-вірної думки. Звичайно це демонструє актуальність даної теми, хоча і не дає нам 
єдиновірної відповіді на більшість питань, які стосуються поняттєвого апарату та методів, які застосовуються. Хоча така невизначеність, дає можливість не лише теоретичного, але і практичного застосування, що i було цілепокладаючою причиною виникнення неформальної логіки.

\section{Список використаних джерел}

Аристотель. Топика. Сочинения : в 4 т. Москва : Мысль, 1978. Т. 2. С. 349-532. Уемов А. И. Основы практической логики с задачами и упражнениями. Одесca, $1997.388 \mathrm{c}$.

Хоменко И. В. Теоретические проблемы неформальной логики: конфликты точек зрения. Эпистемология и философия науки. Москва, 2013. Т. 37, № 3. C. 85-99.

Freeman J. B. The Place of Informal Logic in Philosophy. Informal Logic. 2000. Vol. 20, № 2. P. 117-128.

Hitchcock D. Informal Logic and Concept of Argument. Hardbook of the Philosophy of Science. Philosophy of Logic. Amsterdam, 2007. Vol. 5.

Johnson R. H., Blair J. A. Informal Logic: Past and Present. New Essays in Informal Logic. Windsor, Ontario, Canada, 1994.

\section{References}

Aristotel'. (1978). Topika [Topics]. In Sochinenija [Essays] (Vol. 2, pp. 349-532). Moskva: Mysl' [in Russian].

Freeman, J. B. (2000). The Place of Informal Logic in Philosophy. Informal Logic, 20, 2, 117-128.

Hitchcock, D. (2007). Informal Logic and Concept of Argument. Hardbook of the Philosophy of Science. In Philosophy of Logic (Vol. 5). Amsterdam,

Homenko, I. V. (2013). Teoreticheskie problemy neformal'noj logiki: konflikty tochek zrenija [Theoretical problems of informal logic: conflicts of points of view]. Jepistemologija i filosofija nauki [Epistemology and philosophy of science], 37, 3, 85-99 [in Russian].

Johnson, R. H., \& Blair, J. A. (1994). Informal Logic: Past and Present. In New Essays in Informal Logic. Windsor, Ontario, Canada.

Uemov, A. I. (1997). Fundamentals of practical logic with tasks and exercises [Basics of practical logic with tasks and exercises]. Odessa [in Russian].

\section{Matviienko I. S.}

\section{THE ARGUMENT THEORY: FORMAL CONTRA INFORMAL LOGIC}

The article presents a study of argumentation theory through two binary positions, namely formal and informal logic. A formal approach to argumentation theory provides a clear structure, formal conditions, and a system of reasoning, but as life practice shows, it is not enough to convince oneself to have true judgments and to formulate correct assumptions according to the basic laws of logic. For the sake of persuasion, informal methods should also be used in their argumentation, because communication between people is relative, not permanent. 
The theory of argumentation is being explored in various spheres of human life today, and although its origins date back to Aristotle's time, disciplines such as psychology, jurisprudence, political science, philology, and many others are involved in these issues in addition to philosophy and logic. This is what determines the fact that more and more new approaches to its study and study are built into the theory of argumentation. The traditional theory of argumentation is formal, and it is fundamentally different from the modern one, for which theoretical answers are insufficient and clear practical guidelines are needed. This gap between theory and practice in nineteenth-twentieth-century science has made it possible to formulate an informal approach to argumentation theory.

Key words: thinking, argumentation, formal logic, informal logic, real argumentation. 